\title{
PROPERTY RESTITUTION AND ENDING DISPLACEMENT IN KOSOVO - COORDINATED EFFORT OR AT CROSS-PURPOSES?
}

\author{
Anneke Rachel Smit, School of Law, University of Reading ${ }^{1}$
}

\begin{abstract}
When the Kosovo Housing and Property Directorate (HPD) and Commission (HPCC) were established by the international community in Kosovo in 1999 they were intended to encourage refugees and IDPs to return to their "homes of origin" by making determinations of the property rights attaching to contested dwellings in the region. After a disastrous start due to a shortage of funding and interest, the institutions have been fully functioning with a strong focus on efficiency of operations since late 2002. At the same time, stated purposes in restituting property seem to have shifted from encouraging refugee/IDP returns, to economic reform and invigoration through establishing certainty of private property rights. While these goals are admirable, key opportunities for coordination with other agencies working on different but complementary aspects of refugee/IDP return (such as encouraging interethnic reconciliation and creating a sense of security for ethnic minorities wishing to return) are being ignored. Further, individuals affected by HPD decisions are given little opportunity to participate in the process.

In the absence of other necessary conditions for return, successful HPD claimants are more likely to sell their homes than return to areas where their security cannot be assured, thereby permanently eliminating any possibility of return. The article is based largely on field-work conducted in Kosovo in June 2003 as well as follow-up interviews in July 2003 and January 2004.
\end{abstract}

\section{INTRODUCTION}

Almost five years after the official end of the conflict in Kosovo, housing and property restitution is finally appearing on the agendas of key international actors in that territory. After a troubled beginning, a new priority placed on the issue has seen the full establishment of

$1 \mathrm{PhD}$ candidate, School of Law, University of Reading, on leave from position as Legal Counsel with the Department of Justice Canada (Immigration Law Services). The views expressed in this article are mine alone. I wish to thank Carl Stychin and Christopher Waters for comments on earlier drafts, and the School of Law, University of Reading for generous financial support of the fieldwork on which this article is based. I am also grateful for the assistance and support of staff and Visiting Fellows of the Refugee Studies Centre, Oxford University, during a visiting fellowship in the fall of 2003. 
internationalized institutions dealing with property rights (which in the early years of the UN's mandate in Kosovo suffered from a lack of both moral and financial support). At the same time, efforts have recently been stepped up to increase the return of ethnic minority refugees and internally displaced persons (IDPs) to the area, with the establishment of the United Nations Mission in Kosovo's Office for Returns and Communities (ORC) in late 2001 and the release of ORC's Manual for Sustainable Returns in February 2003.

In principle these two developments should complement each other to encourage reconciliation and the building of a multi-ethnic Kosovo. However, the reverse may in fact be more true: in the push to create certainty of property rights, important opportunities for this process to contribute to return and reconciliation are being ignored. Further, the individuals concerned are largely excluded from any meaningful participation in the process, again missing key chances for interethnic communication and reconciliation and ignoring the emotional impact of losing and/or regaining one's home. In the absence of other conditions necessary for return, refugees and IDPs, when they receive a positive determination of their housing claims, are currently likely to sell their property, permanently eliminating the real possibility of return. This threatens to push Kosovo towards becoming a region with security of tenure but with few non-Albanian minorities.

This article begins with a short overview of the emerging right at international law of a displaced person to return to one's "home of origin". It then describes in some detail the considerable efforts which have been made by the international community in Kosovo to protect the property rights of the displaced and thereby encourage them to return, as well as substantial barriers encountered in the early days of the UN administration. The last half of the article reflects upon how, although the housing and property mechanisms are now fully established and working efficiently, the international community is now failing to effectively coordinate the work of these bodies with other aspects of encouraging return. The paper is based on fieldwork undertaken in Kosovo in June 2003 as well as follow-up interviews conducted in July 2003 and January 2004. It builds on my experience working for Citizenship and Immigration Canada in 1999 in refugee camps established on military bases in Canada following the airlift of Kosovo Albanians from camps in Macedonia during the conflict, and on my work as a Human Rights Officer with the Organisation for Security and Cooperation in Europe (OSCE) Mission in Kosovo from 1999-2000.

\section{The Right Of Return To One's "Home Of Origin"}

The right to return to one's home of origin, and the corresponding right to housing and property restitution for displaced persons, have been increasingly articulated in peace agreements and UN documents in recent years. The 1995 Dayton Accords, for example, laying out the framework for peace in Bosnia and Herzegovina, provided at article II.5 of the Bosnian Constitution that "All refugees and displaced persons have the right freely to 
return to their homes of origin." 2 Security Council resolutions in other situations of mass displacement, such as Georgia/Abkhazia, have subsequently used similar language. ${ }^{3}$

On a rhetorical level, the United Nations High Commissioner for Human Rights (UNHCHR)'s Sub-Commission on Prevention of Discrimination and Protection of Minorities passed a resolution in 1998 entitled "Housing and property restitution in the context of the return of refugees and internally displaced persons" in which it reaffirmed "the right of all refugees [...] and internally displaced persons to return to their homes and places of habitual residence, should they so wish." ${ }^{4}$ This has been followed upon by numerous subsequent resolutions confirming the right of return to home of origin, and linking this to the establishment of effective housing and property restitution mechanisms. ${ }^{5}$ In 2002 a Working Paper studying the question of housing and property restitution was prepared by Sub-Commission member Paulo Sérgio Pinheiro and presented to the Commission on Human Rights. ${ }^{6}$ Pinheiro was then appointed Special Rapporteur on housing and property restitution and returns issues and was commissioned to prepare an extensive report on the issue, a preliminary version of which was submitted to the SubCommission's fifty-fifth session in June 2003. ${ }^{7}$ The preliminary report again recognises the "unique role that housing and real property restitution play in securing the voluntary, safe and dignified return of refugees and other displaced persons to their homes and places of original residence." 8 Similar developments have taken place within other UN bodies, for example the Committee on the Elimination of Racial Discrimination (CERD). ${ }^{9}$

Described by one observer as the "normative response of the international community to the problems and challenges posed by the phenomenon of

2 Constitution of Bosnia and Herzegovina, adopted as Annex 4 of the Dayton Peace Accords, initiated in Dayton, Ohio (21 Nov 1995). Article 1(1) of annex 7 (which deals with refugee and displacement issues) contains an almost identical guarantee.

3 UN Doc.S/RES/1187 (1998), para 3. United Nations General Assembly Resolution 194 on Palestine (A/RES/194 [III] [1948]) also famously resolved at para 11 that "the refugees wishing to return to their homes and live at peace with their neighbours should be permitted to do so at the earliest practicable date, and that compensation should be paid for the property of those choosing not to return and for loss of or damage to property which, under principles of international law or in equity, should be made good by the Governments or authorities responsible." For a comprehensive study of the development of the right to housing and property restitution for displaced persons, see Leckie, "New Directions in Housing and Property Restitution" in Leckie, ed, Returning Home: Housing and Property Restitution Rights for Refugees and Displaced Persons (2003).

4 E/CN.4/Sub.2/Res/1998/26.

5 See, for example, E/CN.4/SUB.2/RES/2002/7. Note that the Sub-Commission changed its name in 1999 to the Sub-Commission on the Promotion and Protection of Human Rights.

6 E/CN.4/Sub.2/2002/17.

7 E/CN.4/Sub.2/2003/11

8 Ibid, p 14.

9 General Recommendation No 22 (1997) (Article 5 on refugees and displaced persons) [A/51/18 (1997)] 
internal displacement", ${ }^{10}$ the non-binding Guiding Principles on Internal Displacement were issued in 1999 by the United Nations Secretary General's Special Representative on IDPs, Frances Deng, after years of discussion on the wording of the text. ${ }^{11}$ Although the document stops short of explicitly guaranteeing an internally displaced person's right to return to the physical structure s/he occupied before fleeing, Principle 28(1) places a responsibility on officials to "establish conditions, as well as provide the means, which allow internally displaced persons to return voluntarily, in safety and with dignity, to their homes or places of habitual residence[.]" Principle 29(1) further requires officials to "to assist returned and/or resettled internally displaced persons to recover, to the extent possible, their property and possessions which they left behind or were dispossessed of upon their displacement" or where this is not possible, to "provide or assist [IDPs] in obtaining appropriate compensation or another form of just reparation". Internationally speaking, then, the link between refugee/IDP returns and housing and property restitution has become well-established.

\section{Early Days In Kosovo}

After an intensive air campaign against the Federal Republic of Yugoslavia in mid-1999, NATO forces agreed to halt the bombing in exchange for the pull-out of Yugoslav forces from Kosovo and an agreement that the United Nations would move in to temporarily administer the territory until a longterm political solution could be reached. The responsibilities of the international community are laid out in United Nations Security Council Resolution 1244.12 These include, at article 11(j), a commitment to assure "the safe and unimpeded return of all refugees and displaced persons to their homes in Kosovo". As described above, this language mirrors the terminology used internationally with increasing frequency.

During the conflict in Kosovo, upwards of 800,000 ethnic Albanians were displaced into refugee camps in neighbouring countries and many subsequently were airlifted further afield to countries including Canada, Australia, the United States and several states of western Europe. While the end of the conflict spurred a massive and spontaneous return migration of ethnic Albanians ${ }^{13}$ large numbers of ethnic minorities - primarily ethnic Serbs - were forced to flee the province. From the beginning it was clear that any movement to assist the ethnic minority IDPs and refugees to return would have to deal actively with the issue of housing and property. Shortly after the UN arrived in mid-1999 to establish a civil administration following

10 Bagshaw, "Developing the Guiding Principles on Internal Displacement: The Role of a Global Public Policy Network", Case Study for the UN Vision Project on Global Public Policy Networks, www.gppi.net.

11 E/CN.4/1998/53/Add.2. Dr. Deng was appointed the UN Special Representative on IDPs in 1992 and from that point worked to develop the Guiding Principles.

12 UN Security Council Resolution 1244 (10 June 1999).

13 In June of 1999, following the signing of the peace agreement for Kosovo, I was among the many working with the Kosovo Albanian refugees who were surprised at the determination of many refugees to return to Kosovo as quickly as possible, regardless of the lack of guarantees for their safety. 
the signing of the Resolution 1244, an official described the situation as follows: ${ }^{14}$

"[I]t appears that up to 150,000 Kosovo Serbs have been displaced into Serbia and Montenegro. Of the 45,000 remaining Serbs, many have been internally displaced into Serb-controlled municipalities. Among the other minority communities in Kosovo (Muslim Slavs, Roma, Turks), which totalled approximately 120,000 individuals before the conflict, it appears that up to 40,000 have left Kosovo. [. . .] Recent surveys calculate that 103,000 housing units are destroyed or otherwise uninhabitable, representing almost half of the housing stock. [. . .] Only 7,000 individuals are currently housed in internationally managed community shelters, indicating that most displaced persons are living with relatives, or are illegally occupying abandoned property."

As described, not only had many houses been destroyed, first by the Serbs during the conflict and then by Albanians in revenge-minded actions after the peace agreement, but there was a high occurrence of "secondary occupation" - individuals or families moving into houses belonging to those who had fled during or after the conflict. For example, many ethnic Albanian families fled to the Kosovo capital of Pristina/Prishtinë ${ }^{15}$ in search of shelter and work during and after the war, occupying homes to which ethnic Serb families, displaced to Serbia proper during the conflict, lay claim. ${ }^{16}$ Likewise, in primarily Serb areas such as North Mitrovice/Mitrovica, ethnic Albanians' homes were occupied by ethnic Serbs. The situation was further complicated by the fact that between 1989 and 1999 many housing allocations had been made by the Serb regime under discriminatory laws, which saw numerous Albanians lose the rights to housing they had previously enjoyed. ${ }^{17}$

Like in so many post-conflict situations, therefore, the importance of housing and property to the issue of refugee and IDP returns in Kosovo cannot be overemphasized, in both humanitarian and legal terms. The establishment of the Kosovo Housing and Property Directorate (HPD) and Housing and Property Claims Commission (HPCC) was thus an important ingredient of fulfilling the international community's commitment in this regard. The United Nations Human Settlements Programme (UN-HABITAT) was enlisted in late 1999 - early days of the UN administration in Kosovo - to coordinate the housing and property restitution process, at least as an interim measure until local mechanisms had been created to take over this function. It was the first time this agency had been involved in field operations in

14 Das, "Regularizing Housing and Property Rights in Kosovo", p 2, <www. unhabitat.org>.

15 Note that throughout this article I have referred to towns and villages within Kosovo by both their Serbian and Albanian names.

16 See, for example: Beardsley, "Who owns what? UN tackles Kosovo housing tangle" (10 January 2002) Christian Science Monitor, <www.csmonitor.com>.

17 Leckie, "Resolving Kosovo's Housing Crisis: Challenges for the UN Housing and Property Directorate" (April 2000) 7 Forced Migration Review 7 at 7. 
Europe, and the first time it had been given responsibility for coordinating quasi-judicial mechanisms. ${ }^{18}$

Importantly, justifications for the funding and efforts to be put into housing and property restitution were clearly linked to encouraging refugee and IDP returns. An early briefing paper prepared by the then- Senior Legal Advisor to the Housing and Property Directorate in Kosovo stated: ${ }^{19}$

"As the Bosnian experience shows, an orderly refugee return process requires a balance between the legal rights and humanitarian needs of different groups of people. Unless housing and property rights are addressed, any attempt to return minority refugees will raise severe political and practical problems. Because it combines a number of different functions within a single institution, the Directorate is potentially a very useful institutional tool for managing the return process."

Three individuals were appointed in August 1999 to be the first members of a quasi-judicial housing and property rights commission. ${ }^{20}$ They were a South African with 5 years' experience as a judge on the Land Claims Court of that country, a Finn with a background in mass claims at UN tribunals, and a Kosovo Albanian who is a former justice of the Kosovo Supreme Court (the same three members continued to sit to January 2004). ${ }^{21}$ Then in November 1999 United Nations Mission in Kosovo (UNMIK) Regulation 1999/23 officially created the HPD, which would receive and process property claims, and the independent HPCC, which would adjudicate them..$^{22}$ Although the regulation allows for several panels to sit concurrently, only one - composed of the original three appointees - was created.

Unfortunately, the progress on housing and property issues seemed to stop there for the time being. While some housing cases had been brought before the municipal courts prior to the signing of the founding regulation, with the creation of Regulation 1999/23 jurisdiction for all housing cases was removed entirely from the domestic courts,$^{23}$ leaving property rights cases in a vacuum until the international mechanisms were up and running. This could not happen before the Rules of Procedure for HPD/HPCC were passed. Instead of pushing ahead to get the necessary institutions up and running, the UN became preoccupied with matters of setting up functioning local

18 UN-HABITAT is based in Nairobi, Kenya. The organisation's mandate is "to promote socially and environmentally sustainable towns and cities with the goal of providing adequate shelter for all" ("Overview" $<$ www.unhabitat.org $>$ ).

19 Supra n 14.

20 "UN launches panel to regularize property rights in Kosovo" (17 August 1999) Complete Kosovo Coverage, <www.un.org/peace>.

21 The Kosovo Albanian member rescues himself from cases in which he has previously been involved in his capacity as member of the Supreme Court. See also the book chapter written by the two international judges: Dodson and Heiskanan, "The Housing and Property Directorate in Kosovo" in Leckie, ed, supra $\mathrm{n} 3,225$.

22 UNMIK/REG 1999/23.

23 This was in line with standard legal interpretation in Kosovo. 
administrations and the criminal justice system, and too little attention was paid to the housing question. ${ }^{24}$

Even the Organisation for Security and Cooperation in Europe (OSCE) which among the internationalized structures has the human rights monitoring mandate in Kosovo, ${ }^{25}$ devoted relatively little energy to advancing property issues. ${ }^{26}$ While the organisation participated in an early Working Group on property rights, and the Kosovo International Human Rights Conference, held in December 1999 in Pristina/Prishtinë, included a panel discussion on property rights, little else was done during the first year of the mission. By the spring of 2000 elections had become the primary focus for the OSCE, and property issues were often shoved aside. Finally in September 2000, the OSCE published a report entitled "The Impending Property Crisis in Kosovo" in which it emphasized the scale of the property rights problem and called on the international community to step up to dealing with the issue: ${ }^{27}$

"The system for the protection of property rights in Kosovo is approaching crisis point. The level of destruction, both of physical property and of records, the years of discriminatory legislation, and the mass movements of persons since 1989 has led to a near total collapse in the structures that previously existed for the protection of property rights. The emerging property crisis is aggravated by the lack of an effective policy response by the international community [. . .] without a resolution of the property issue, the situation of internally displaced persons (IDPs) and refugees is aggravated since their homes are often occupied or destroyed."

The OSCE report called on the UN to ensure that HPD was fully functioning in Kosovo by the end of 2000. In October of that year UNMIK Regulation 2000/60, containing the HPD/HPCC Rules of Procedure and outlining many of the details of how the institutions were to function, was finally passed. These included the fact that HPCC members would sit as one panel and normally decide by consensus. ${ }^{28}$ Generally speaking the basis for HPCC's

24 The UN has been criticized for focussing on criminal justice in Kosovo to the exclusion of civil justice (interview with an OSCE Human Rights Officer, Pristina, 16 June 2003). As many of my interviewees continue to hold either the same position as when I interviewed them, or another position with an international organization in Kosovo or elsewhere, I have preserved their confidentiality by referring only to their job titles in the most general way possible unless they have given me permission to do otherwise.

25 And whose staff have sometimes been described as the "tree-huggers" of the international community in Kosovo for their single-minded insistence on compliance with international human rights standards (ibid).

${ }^{26}$ It has been asserted that one reason for this may have that some members of staff of international organisations were illegally occupying housing belonging to displaced persons in the early days of the international mission, making it a sensitive area to tackle (ibid).

27 "Background Report: The Impending Property Crisis in Kosovo", OSCE Mission in Kosovo (25 September 2000), p 1, <www.osce.org>.

28 UNMIK/REG/2000/60, s 20.3 . 
determination was to be what property rights (ownership or possession ${ }^{29}$ attached - or, would have attached but for discriminatory practises - to the dwelling in question as of March 24, 1999. ${ }^{30}$ While the current occupier of the property would be permitted to make submissions to HPCC, the only documents of relevance would be those which would go to proving that s/he was the lawful owner/possessor on the relevant date. According to Regulation 2000/60 HPCC was given jurisdiction to determine three types of cases. These are Category A - claims by individuals who lost property as a result of discriminatory laws after 1989, Category B - claims by persons who entered into unofficial transactions for the sale of their property, and Category $\mathrm{C}$ - claims by refugees and displaced persons who have lost possession of their property. ${ }^{31}$

While the passing of the Rules of Procedure in principle allowed HPD/HPCC to push ahead with property rights determinations, the reality was a different story. UN-HABITAT's operations were funded almost entirely from voluntary contributions and its administration was run from its headquarters in Nairobi. This combination led to the organisation being under funded and its administrative procedures unduly complicated. The result was that staffing and the purchasing of key equipment such as vehicles, was extremely difficult, leaving field operations severely restricted. ${ }^{32}$ Repeated warnings by the organisation that funding was desperately in need in order for it to continue its work were not heeded. ${ }^{33}$ Due to lack of funding HPD/HPCC had to curtail their claims determination operations to only processing claims which had already been received.

By July 2002 a full crisis - of both budget and morale - had developed within the organisation. While HPD offices had finally been nominally set up in 4 of the 5 regions of Kosovo (Prizren's claims were being dealt with by the office in Pec/Pejë), most claims were being dealt with from Pristina/Prishtinë and, although a total of 17,785 claims had been accepted by September 2002, only 448 had been determined. ${ }^{34}$ HPD staff reportedly predicted at that point that it would be 10 years before all the claims had been dealt with. ${ }^{35}$ The HPD Periodic Report of June 2002 stated: ${ }^{36}$

"The HPD continues to experience a serious lack of funding and consequently, a lack of staff. The organization has the technical knowledge, and procedures needed to complete the

29 Much of the housing stock in Kosovo before the conflict was socially-owned housing allocated to workers by state-owned enterprises.

30 Supra n 28, s 2.

31 Supra n 22, s 1.2.

32 Telephone interview with former HPD international staff member, 12 January 2004.

33 HPD's quarterly report for January-March 2002 gravely predicted: "The HPD continues to work with UNMIK, UN-HABITAT and donors to resolve the funding crisis. Without resolution of this issue, the HPD will close in Kosovo in September 2002 and in its entirety in December 2002" (HPD Periodic Report, JanuaryMarch 2002, <www.hpdkosovo.org>).

34 HPD Periodic Report, April-June 2002; HPD in 2003 - Annual Report, p 1, <www.hpdkosovo.org>.

35 Interview with HPD international staff member, Pristina/Prishtinë, 12 June 2003.

36 HPD Periodic Report, April-June 2002, supra 34. 
mandate within a reasonable time. However, severe personnel and equipment shortages have forced the office to run with a skeletal staff core that is struggling to keep the institution functioning. Many international officers have been tasked with the duties of two, sometimes three persons, which has resulted in reduced production, job insecurity and staff turnovers."

At a donor conference in the same month, the Executive Director of UNHABITAT and the UNMIK Deputy Special Representative of the Secretary General (second in command in the UNMIK structure) jointly warned that HPD was "in danger of collapse due to funding constraints". ${ }^{37}$

\section{A New Approach}

Thankfully, this unsettling upheaval in mid-2002 was the beginning of a sea change with respect to funding and priority for property rights determinations in Kosovo. Following the signing of a Memorandum of Understanding between UNMIK and UN-HABITAT in July, by November UN-HABITAT had handed over all the HPD/HPCC operations within Kosovo to UNMIK, ${ }^{38}$ retaining responsibility only for satellite offices in Belgrade (Serbia), Podgorica (Montenegro) and Skopje (Macedonia). A new Executive Director of HPD/HPCC, the former Deputy Head of Mission of OSCE in Kosovo, was appointed, and a Director of Legal Process, an American lawyer with experience in mass claims, was brought in to manage the claims operation. Perhaps most importantly, sufficient funding to get the organisation fully up and running was secured from donors.

Since their reconfiguration HPD and HPCC have put a mammoth push on the determination of property rights claims. HPD has established, and fully funded and staffed, offices in all five regions and has decentralized much of

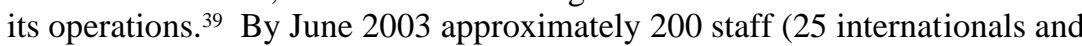
175 nationala) had been employed by HPD, spread out through headquarters and the regions.

The final deadline for the submission of claims (having been twice extended) was July 1,2003 , by which time a total of 28,832 claims had been received. ${ }^{40}$ Of these almost 13,000 claims had been resolved by the end of $2003 .{ }^{41}$ More than $95 \%$ of these determinations were made between November 2002

37 UNMIK Press Release, UNMIK/PR/764, 24 June 2002.

38 UNMIK Press Briefing Notes, 11 November 2002, <www.unmikonline.org>.

39 Regarding funding, however, note that HPD/HPCC are donor-funded as opposed to other UN agencies which receive "core UN funding". Generally speaking this results in far less generous financial support for HPD/HPCC than other UN agencies in Kosovo receive. A visit to HPD offices in Pristina/Prishtinë and Pec/Pejë, and by comparison UNMIK headquarters, in June 2003 made clear the difference in funding levels - HPD offices are sparsely furnished, with many staff sharing one office, and in the case of the Pec/Pejë office water damage from above was threatening to ruin hundreds of files stored in the Regional Director's office.

40 HPD in 2003 - Annual Report, supra n 34, p 1.

41 Ibid. 
and December 2003, and HPD has received positive feedback in both media and OSCE monitoring reports for its streamlined operations and efficiency. ${ }^{42}$

Along with much improved funding, HPD staff hold up their new "mass claims" approach as a key reason for their efficiency relative to their UNHABITAT predecessors. ${ }^{43}$ HPCC functions on a case-law system and as such is bound by precedent. ${ }^{44}$ The mass claims approach means that rather than determining each case individually, claims are grouped according to similar facts. ${ }^{45}$ A representative sampling of cases (approximately 10) is taken from each fact scenario in order to assess how a decision might impact on a number of variations on a theme, and then a decision is made. This decision is then to be applied to the rest of the cases in the group, and determinations made and communicated to claimants. ${ }^{46}$

The goal is reportedly to have completed the rest of the straightforward claims in 2004, the difficult cases in 2005 and to shut down the institutions entirely by $2006,{ }^{47}$ having completed the task of making a property rights determination for every contentious residential property in Kosovo. Given progress to date, there is little reason to doubt that HPD/HPCC will accomplish the task within their stated timeline or near to it.

\section{Housing and Property Restitution and Refugee Returns}

Should the revamped HPD/HPCC therefore be hailed a success? On their face, the numbers do tell a success story. Operations of the agencies have been streamlined since the restructuring, and moving to a mass-claim system is allowing HPCC to churn through claims at a speed which could not be contemplated when UN-HABITAT was running the show. All this has been done on a far less generous budget than most UN agencies in Kosovo. It is also alleviating concerns that claimants' rights under article 6(1) of the European Convention on Human Rights were being violated due to the length of time it was taking to process claims. ${ }^{48}$ HPD/HPCC's accomplishment of improving the efficiency with which claims for property

42 See, for example: Islami, "Kosovo: Housing Dispute Breakthrough" (2 January 2003) Institute for War and Peace Reporting, <www.iwpr.net>; "Property Rights in Kosovo, 2002-2003", OSCE Mission in Kosovo Department of Human Rights and Rule of Law, pp 14-15, <www.osce.org/kosovo>.

43 Supra $\mathrm{n} 35$.

44 See "Index - HPCC Decisions no. 1-71 (16 th $^{\text {th }}$ Commission session)" and "Summary of HPCC decisions", both documents produced by HPCC and on file with the author.

45 In particular, cases with similar circumstances with respect to how secondary occupiers gained the opportunity to possess the property they currently occupy for example those with permits granted by KFOR (the NATO military peacekeeping force in Kosovo) or the TMK (the descendents of the Kosovo Albanian paramilitary organization KLA) are grouped with other cases of the sort.

46 Supra $\mathrm{n} 35$

47 Ibid.

48 Convention for the Protection of Human Rights and Fundamental Freedoms as amended by Protocol No. 11. Article 6(1) states: "In the determination of his civil rights and obligations or of any criminal charge against him, everyone is entitled to a fair and public hearing within a reasonable time by an independent and impartial tribunal established by law" [emphasis added]. 
are dealt should therefore not be underemphasized. However, it is clear that the current push towards the quick and efficient determination of property rights in Kosovo has more to do with establishing the rule of law and jumpstarting a capitalist economy (through the provision of legal certainty over property rights) than with the original goal of contributing to the refugee/IDP return process, or reconciliation within deeply wounded communities.

While the importance of certainty of tenure to the stimulation of postsocialist economies has been widely argued, ${ }^{49}$ such effects are difficult to quantify, particular in relatively early days in Kosovo. Nonetheless, the desire to improve the economy has become a guiding force for HPD/HPCC. The organisation's 2003 Annual Report states, "a determined effort is underway to ensure that a market economy takes root in Kosovo. Privatization is intertwined with the regularization of the property market, emphasizing the importance of rehabilitating housing and property rights." 50 The focus on certainty of property rights seems to correspond with the international community's (and specifically western donors') preference for projects which are seen as leading directly to a revival of Kosovo's economy. Another recent funding favourite has been the UN's Kosovo Trust Agency, tasked with privatization of the territory's socially-owned enterprises. Both of these institutions have reportedly been under pressure to "get it done before the funding runs out" (i.e. before donor interest turns elsewhere). One OSCE Human Rights Officer stated that "what we are witnessing here is a fifth gear transition to a market economy". ${ }^{51}$

However a thriving and self-sufficient economy is not the only entity the international community is committed to building and nurturing before it leaves Kosovo. A new "Standards for Kosovo" document, released by UNMIK in December 2003 and outlining the conditions which must be met before the region's political status is determined and UN control over governing is handed over to local authorities, envisages "a Kosovo where all - regardless of ethnic background, race or religion - are free to live, work

49 See, for example: de Soto, The Mystery of Capital: Why Capitalism triumphs in the West and fails everywhere else (2000); Batalov, "Note and Comment: The Russian Title Registration System for Realty and its Effect on Foreign Investors" (1998) 73 Wash. L. Rev. 989; Gerson, "Peacebuilding: The Private Sector's Role" (2001) 95 A.J.I.L. 102; Eyre and Wittkowsky, The Political Economy of Consolidating Kosovo: Property Rights, Political Conflict and Stability (May 2002) Friedrich Ebert Stiftung, <http://library.fes.de>.

50 HPD in 2003 - Annual Report, supra $\mathrm{n} 34$.

51 Supra n 24. The privatization task, too, is not without its complications: see Matic, "Serbia Angered by Kosovo Privatisation" (30 May 2003) Institute for War and Peace Reporting; and Qirezi, "Kosovo: Mixed Feelings at Steiner Exit" (6 June 2003) Institute for War and Peace Reporting, both available at <www.iwpr.net>. On 7 October 2003 the privatization process was at least temporarily halted following ongoing protests from Belgrade about the legality of the process [see Grubanovic, "Privatization Halted" (13 October 2003) Transitions On-line, <www.tol.cz>]. This "rush to privatize" has been criticized in other postconflict contexts. See, for example: "Iraq economy: Say no to privatization" (23 September 2003) The Guardian A17 (editorial). 
and travel without fear, hostility or danger and where there is tolerance, justice and peace for everyone." ${ }^{52}$

Further, as stated above, the international community pledged in Resolution 1244 to oversee "the safe and unimpeded return of all refugees and displaced persons to their homes in Kosovo" [emphasis added]. The link between housing and property restitution and refugee/IDP returns was made explicit at the time that HPD/HPCC were created. This was reflected both in statements made by high-ranking UN officials at the time, as well as in one of the founding regulations of the institutions: Regulation 2000/60 clearly incorporated the protection of the right of return into the mandate of HPD/HPCC, stating: "Any refugee or displaced person with a right to property has a right to return to the property, or to dispose of it in accordance with the law, subject to the present regulation." 53 Unfortunately, there exists a very real fear on the part of many involved in the returns process (including refugees and IDPs themselves) that rather than encouraging return and reconciliation, HPD/HPCC's current approach will in fact be detrimental to many of the international community's social goals. In the remainder of this paper I highlight two elements of HPD/HPCC's approach which may be having an adverse effect on these aims.

\section{(a) Lack of coordination with returns agencies/organisations}

First, a failure of coordination between HPD/HPCC and other agencies working on key aspects of return means that many displaced persons receiving a positive determination of their housing and property claims from HPCC do not feel that return is a real option, since other conditions necessary for successful return are not provided for at the same time. Part of the blame for this can arguably be laid at the feet of HPD/HPCC: it seems that the organisations may now be slaves to the (at least perceived) narrowness of their defined task, i.e. to make a determination of the housing and property rights attaching to each contested dwelling in Kosovo. While HPD and HPCC were originally envisaged as a "potentially very useful tool for managing the return process" 54 the goal has become much narrower. The simplicity of the mandate makes the prospect of finishing the task in the near future seem much more attainable. But the encouragement of refugee/IDP returns, and particularly the coordination of property determinations with other elements of return, seems often to be forgotten.

Ostensibly returns do remain an important aim of HPD/HPCC. The opening line of the $2003 \mathrm{HPD} / \mathrm{HPCC}$ Annual Report states: "The fundamental right to property and accommodation is a prerequisite for the sustainable return of refugees and the internally displaced in post-conflict situations." ${ }^{55}$ However, HPD's Director of Legal Process emphatically states: ${ }^{56}$

52 UNMIK/PR/1078 (13 December 2003). See also Greicevci, "New Standards for Kosovo" (15 December 2003) Transitions On-line, <www.tol.cz〉.

53 Supra n 28, s 2.5.

54 Supra $\mathrm{n} 14$

55 Supran 34.

56 Interview with HPD Director of Legal Process, Pristina/Prishtinë, 12 June 2003. One of the HPD's regional directors also used the "we're not in the returns business" catchphrase when I spoke with him, suggesting that this is a sort of 
"We're not in the returns business. Of course we're part of the returns process, but we're not a returns organisation. Just like we're part of the process of creating law and order in Kosovo but we're not the police. Returns are for [the UN agencies with responsibility for refugees/IDPs] to deal with. But if we do housing and property rights determination intelligently then it's up to people to return or not."

Rather than the task being seen as a positive obligation to ensure the right to return, therefore, the obligation now seems to be viewed as a negative one HPD/HPCC's job is simply to ensure that no one is actively deprived of the right to return due to a lack of housing and property restitution.

There is obviously a political aspect to this approach as well. The Director of one HPD regional office formulated the interplay between his office's role and returns in the following way: ${ }^{57}$

"Housing and property restitution has been used as a scapegoat by local political leaders to explain why returns have not happened. At the time of handover - that is, when the United Nations leaves Kosovo - either UNMIK or the elected [local] officials are going to have to explain why returns are not happening. If property rights determinations have been made, then that blame cannot be put on the UN/HPD, and the burden of explaining will be on the elected [local] officials."

Ultimately whether or not to return is a personal choice for each displaced person or family, and property restitution is simply seen as giving people the option. However, it must be asked how real the option really is when displaced individuals are left holding a piece of paper affirming their right to their home, yet knowing that if they try to exercise that right they will find a plethora of other obstacles: for example, returning might make them the only people of their ethnic group in the village, they may not have a means to support themselves, and a range of other services may not be available to them in a language they speak.

The landscape has admittedly changed since the "first" HPD was created, and other mechanisms have been developed in attempts to facilitate returns to Kosovo. ORC's Manual for Sustainable Return, in encouraging the development of projects for return, foresees the cooperation of - among others - NGOs, the local municipalities, the displaced populations themselves, and ORC (which is primarily responsible for procuring donor funding for return projects). ${ }^{58}$ ORC has established working groups for

mantra for the organisation. In some ways this may not be entirely new, however. One veteran of the earlier incarnation of HPD suggested that refugee returns were always a justification which could be emphasized when speaking to potential donors about HPD's activities, even if in reality they did not always constitute a real focus for the organization (supra $\mathrm{n} 32$ ).

57 Interview with an HPD Regional Director, Kosovo, 11 June 2003. Stated another way, the current approach seems more geared towards "putting property rights in a holding pattern" than actually encouraging returns (supra $\mathrm{n} 35$ ).

58 Manual for Sustainable Return [published by ORC and United Nations High Commissioner for Refugees (UNHCR)], January 2003 edition, <www.unmikonline.org>. 
return in 24 of Kosovo's 30 municipalities and may be understood to be overseeing international efforts to assist the returns process in those areas. ${ }^{59}$

These would seem to be potentially important venues for the coordination of return efforts with property rights determinations. HPD representatives do sometimes attend the inter-agency working groups on returns, although their attendance is not mandatory (and indeed is not even contemplated by the Operational Guidelines set out in the Manual). However, little actual coordination reportedly goes on with respect to property rights. One OSCE Human Rights Officer who attended such meetings stated: "I constantly had to warn members of the working group that 'if you don't pay attention to it this property issue is going to blow up". ${ }^{60}$

HPD staff state they have told ORC that if there is a specific area being considered for a returns programme, HPD could be willing to do all the claims determinations for that village at once and in priority in order to help facilitate a return movement. ${ }^{61}$ Occasional offers to collaborate with ORC on a plan of return (for example to accelerate the determination of claims in originally Serb villages in a corridor reaching from the Serbian border and encircling Pristina/Prishtinë so that a returns plan could be implemented there) have reportedly never been taken up by ORC. ${ }^{62}$ ORC staff for their part seemed unaware that HPD would be willing to approach claims in such a way. ${ }^{63}$ Staff of UNHCR (the United Nations High Commissioner for Refugees) in Serbia working with ethnic Serb IDPs from Kosovo also express frustration at the lack of information they receive from HPD, even when such communication is requested. One Protection Officer states that if her office had ever been given the opportunity to suggest areas for prioritized claims determination, it would have helped them immensely in facilitating return of the IDPs the office works with. ${ }^{64}$

Instead, many IDPs who have submitted claims to HPD find themselves with few options even when they receive a positive determination of their claim. As one ethnic Serb IDP originally from Urosevac/Ferizaj stated: ${ }^{65}$

59 These meetings are held in each municipality, chaired by the UN Municipal Administrator, and are attended by the President of the Municipal Assembly [interview with ORC international staff member, Pristina, 13 June 2003; ibid., Part II-5]. Regional Working Groups also exist to coordinate the activities within each region.

60 Supran 25

61 Supra $\mathrm{n} 35$

62 Ibid.

63 Interview with ORC international staff member, supra $\mathrm{n} 59$.

64 E-mail communication with UNHCR Protection Officer, Serbia, 2 July 2003.

65 Interview with ethnic Serb male IDP in central Serbia, originally from Urosevac/ Ferizaj, 4 July 2003 . One complication to this approach, not mentioned by current HPD staff members but encountered by CRPC in Bosnia, is the difficulty within a strictly rights-based system of determining one person's claim in priority to another, even if the latter had made his/her claim first (supra n 32). A UNHCR Protection Officer in central Serbia did report that some Serb IDPs in that area were concerned that their neighbours who had made their claims much later than they might receive their HPCC decisions first if claims were prioritized by village (ibid.). 
"I filed my HPD claim in 2001. At first I thought of a possibility to return but knowing that no one else returned to the place made me feel insecure. I have children and it would be very difficult for them to live there."

The same IDP stated that if HPD had been able to arrange to settle the claims of, for example, all the Serbs living on his street in his home village at the same time, he may have been more willing to contemplate a return. Instead, when he received his positive determination, he simply sold his house, thereby eliminating any practical likelihood of his family ever returning to Kosovo.

HPD staff fully admit that the organisation's role is not coordinated with other bodies when it comes to returns, but lay some of the blame for this on other institutions' lack of efficiency. As one HPD international staff member stated, ${ }^{66}$

"We're moving too fast for [the rest of the UN]. If we are able to make even 500 HPCC decisions per month [half the current average], are the police prepared to protect those 500 properties when people are evicted? Is ORC prepared to organise the return of 500 families per month to their homes?"

At present the answer to both of these questions is quite clearly no. It is simply not possible for Kosovo's police force to protect all properties. While Kosovo has at present approximately 9,500 international and national police officers, ${ }^{67}$ the problems of maintaining law and order in the province are seemingly endless and there is no guarantee that the police would be able to provide adequate protection for houses vacated following HPCC decisions, even if they attempted to do so. ${ }^{68}$ Further, the police are at present not even informed by HPD when an eviction (carried out by HPD Evictions Officers) is to take place. The result is that homes are often burned either by occupants as they are leaving under an eviction order or afterwards while they sit empty. The same ethnic Serb IDP quoted above recounts: "HPD actually evicted the family from my house but by the time I had the key back from HPD and visited the place the house was looted and almost completely destroyed." 69

A new HPD policy is reportedly helping to change this: even when a property determination has been made, current occupants are now not evicted until the rightful owner declares his/her firm intention to return. ${ }^{70}$ However, even so, once an eviction order has been made the owner has 14 days in which to return. Although houses are "sealed" by HPD during this period, in practise homes are sometimes damaged or burned to the ground. Generally speaking, too, the role of the police in investigating and prosecuting

66 Supra $\mathrm{n} 35$.

67 As of 22 February 2004. This includes approximately 3,700 international police and approximately 6,000 national police officers.

68 See, for example, "Violence Destabilizes Kosovo" (13 August 2003) Transitions On-line; Greicevci, "First UNMIK Casualty in Kosovo" (11 August 2003) Transitions On-line, both at <www.tol.cz>.

69 Interview with ethnic Serb male IDP in central Serbia, supra $\mathrm{n} 65$.

70 Supra $\mathrm{n} 35$. 
property-related offences has not been clear (although a Memorandum of Understanding between the police and HPD has reportedly been signed recently). ${ }^{71}$

Further, while ORC is working to encourage returns as quickly as possible, even if individuals were willing, nowhere near 500 individuals could at present be coordinated and convinced to return home each month under the auspices of the ORC. During 2002 only about 2,000 ethnic minority IDPs returned to Kosovo; ethnic minorities displaced from Kosovo still numbered an estimated 40,000 at the end of that year. ${ }^{72}$

While HPD's current approach does reflect positively on the organisation's efficiency, especially given its limited resources, the lack of interest in coordination, both from HPD's perspective and ORC's, does little to develop a well thought-out and workable approach to returns. The right to return has been described as "a composite of many different, interlocking legal rights"; ${ }^{73}$ the failure of the international community to effectively coordinate the activities of the organisation tasked with protecting one of the most key rights with those working on other elements of return jeopardizes the process.

\section{(b) Lack of owner/occupier involvement in procedure for claims determination}

A second, related, failure of the current approach to property rights determination in Kosovo is in the lack of concerned individuals' active involvement in the process. While the mass claims approach has radically improved the efficiency of HPD/HPCC, important opportunities for communication and reconciliation between parties - which could ultimately assist in creating the security conditions necessary for return - and for individuals to feel a sense of ownership over the decision made, are being lost.

In a 2001 article Day criticised the procedure used by the Commission for Real Property Claims (CRPC) in Bosnia-Herzegovina as excluding the claimant (generally the displaced person) and particularly the respondent (the

71 E-mail communication with an OSCE Human Rights Officer, Kosovo, 30 June 2003.

72 UNMIK Office of Returns and Communities 2003 Strategy for Sustainable Returns, document produced for Donor Co-ordination Meeting for Kosovo, Brussels, 5 November 2002, p 4. Note that such figures generally track only inmigration and not those displaced persons who subsequently decide to leave again, meaning that numbers of returnees may be inflated. The number of minority returns is said to have increased during 2003, however comprehensive statistics are not yet available at time of writing.

73 Besides property rights, this includes personal security and freedom from discrimination [Cox and Harland, "Internationalized Legal Structures and The Protection of Internationally Displaced Persons" in Fitzpatrick, ed., Human Rights Protection for Refugees, Asylum Seekers, and Internally Displaced Persons: A Guide to International Mechanisms and Procedures (2003) 521 at 524-5]. 
secondary occupier, who may in turn also be a displaced person from another region) from meaningful participation in the determination process: ${ }^{74}$

"Notwithstanding the inability of participants to accept or reject the outcomes within an adjudicatory model, other aspects of the CRPC draw into question the level of satisfaction among participants. [T] he level of participation by the claimant is potentially minimal, limited for the most part to the initial consultation and filing of a claim. More troubling still is that no provision exists to ensure the participation of the second-occupier [. . .] Even if justice demands that the returnee has a right to reclaim the land, the second-occupier should not be denied an opportunity to participate in the decision, nor should the procedure be ostensibly so unequal."

Describing the CRPC's (and the rest of the international community in Bosnia's) failure to encourage a real return movement, Phuong also predicted that similar challenges would arise in Kosovo: $:^{75}$

"Determined efforts have been made in Bosnia and Herzegovina to resolve property disputes against a background of war and ethnic division. The number of minority returns has been less than anticipated. The same problems, and the same dilemmas, will recur in Kosovo should displaced Serbs one day decide to try to return to homes now occupied by Kosovans."

While largely modelled on the Bosnian example, the structures of HPD and HPCC have incorporated some subtle improvements over CRPC. ${ }^{76}$ Despite these small changes, however, not enough has changed: much of Day's criticism of CRPC in Bosnia could also fairly be levied against HPD/HPCC in Kosovo. Human rights monitors in Kosovo state that there is still not enough of a "best practises" approach taken - more could be learned from what has worked or failed in Bosnia and other post-conflict situations when attempting to deal with property issues in Kosovo. ${ }^{77}$

Although a claimant must go in person to an HDP office to make a claim thereby ensuring at least one opportunity to talk to someone about what has happened to her/his home - the process is more administrative than a real

74 Day, "Alternative Dispute Resolution and Customary Law: Resolving Property Disputes in Post-Conflict Nations, a Case Study of Rwanda" (2001) 16 Geo. Immigr. L. J. 235 at 245.

75 Phuong, "At the heart of the return process: solving property issues in Bosnia and Herzegovina" (April 2000) 7 Forced Migration Review 5 at 7. On housing and property restitution in Bosnia-Herzegovina, see generally: Hastings, "Implementation of the Property Legislation in Bosnia-Herzegovina" (2001) 37 Stan. J. Int'l L. 221; Prettitore, "The Right to Housing and Property Restitution in Bosnia and Herzegovina: A Case Study" (April 2003) paper prepared for BADIL Expert Forum for a Rights-Based Approach to the Palestinian Refugee Question 2003-2004, <www.badil.org>.

76 Supra $\mathrm{n} 24$.

77 Some positive steps are being taken to bring together "best practices" worldwide however: see, for example Leckie, ed, supra $\mathrm{n} 3$; and Cox and Harland, supra $\mathrm{n}$ 73. 
chance to give testimony. Likewise, once the claim has been made, the current occupant of the house will be invited to go to the HPD to make a statement and submit any relevant documents. ${ }^{78}$ This involvement of the secondary occupier is perhaps the most significant improvement over Bosnia. ${ }^{79}$ The two parties may also be contacted separately by the legal officer investigating their claim if additional information is needed. Other than this, however, there is no further involvement on the part of the two parties. The parties are not permitted to give any testimony before the HPCC, and there is no hearing for them to attend even as observers. They are simply made to wait, often several months, before being informed by letter once a decision is made in their case. In the meantime, accessing information from HPD on the status of their claims or the claims against them is reportedly very difficult. ${ }^{80}$ The parties may be left feeling like very passive participants in the process. Further, when the HPCC decision is made it is binding and, while there is a mechanism in place for requesting a reconsideration of the decision, this is done by the same body which issued the first decision. There is no opportunity for appeal. ${ }^{81}$

Nowhere in the process, then, is there a formalized opportunity (or requirement) for the two parties to meet or in any way work together to come to an agreement. Interestingly, Regulation 2000/60 did envisage a role for mediation, with HPD staff meant to coordinate this activity. Section 1.2 states in part:

"The Directorate shall refer [. . .] claims to the Housing and Property Commission for resolution or, if appropriate, seek to mediate such disputes and, if not successful, refer them to the Housing and Property Claims Commission for resolution."

The original idea was therefore that the Claims Commission would function only "where mediation is not appropriate". ${ }^{82}$ However, no steps were taken to ensure that HPD offices were staffed with someone who had experience in mediation, and in the new push towards efficient procedures, the mediation option has been dropped altogether. An international member of HPD's staff

78 As discussed above, however, the only relevant documents are those which prove ownership/possession rights on the relevant date.

79 Also an important improvement is a "humanitarian permit" regime allowing those who truly have nowhere else to go to be granted an abandoned or HPDadministered house to live in on a temporary basis. This is still a very bare-bones approach which can provide assistance for only the most destitute of applicants. The HPD website states "The HPD's limited properties dedicated for humanitarian use are primarily meant for people whom the HPD must evict from other properties which were the subject of a successful claim but who would literally have no other place to go but onto the street. The HPD cannot vouch for the quality of these properties, only that they have four walls and a roof" ("HPD: Frequently Asked Questions", <www.hpdkosovo.org>).

80 Supra $\mathrm{n} 64$

81 Further, there have been accusations of HPD bias amongst both the Albanian and Serb communities which will detract from the feeling of satisfaction or closure parties may experience following the conclusion of the procedure: interviews with an HPD Regional Director, supra n 57, and an OSCE Human Rights Officer, Kosovo, 13 June 2003.

82 Supra 14. 
states, "No one in their right mind could have thought that [mediation] could work in a mass-claim process." The staff member continues: ${ }^{83}$

"[W]hen it was tried on some test cases, it was basically the parties haggling over prices. It's not like there is a dispute which can be compromised - one party had a right to the property but no possession and the other party had possession but no right. So either the property was sold or it was not. There really wasn't anything the HPD lawyers could do. If the HPD lawyers tried to take an active role, they basically became real estate brokers, which presented a conflict of interest. If the parties agreed on a price, they did not need the HPD to mediate. If the parties did not agree on a price, there was not much the HPD could do but sit there and let things drag on. To have this be a serious step in a mass claims process would have dragged this on forever. So active mediation was quickly abandoned."

Of course it is still possible for claimants and current occupiers to contact each other privately, and HPD does still declare itself willing to assist in these matters by providing contact information if both parties are interested. However, as suggested in the quotation above this generally only happens when the claimant owns the house in question and is interested in selling it to the occupier. Any negotiation which takes place is really only on the level of trying to agree on whether a sale will take place and what the price will be. ${ }^{84}$

Further, when a decision is made against the current occupant and the rightful owner wishes to return to the home, the occupants are served concurrently with an eviction order requiring them to quit the premises within 14 days. If they do not do so, on the expiry of the notice period an HPD Evictions Officer will come to the property and enforce the eviction, which may involve physically removing all the occupiers' belongings from the house if they still remain. The owner is not to be present at the home until the house or flat is empty.

On one hand the lack of parties' personal involvement in the new HPD/HPCC procedures, and specifically the lack of a role for mediation, makes perfect sense - there is a simple legal determination to be made, and with the relevant documentation provided, the Commissioners need simply to be left to make it. There is only one rightful owner or occupier according to the criteria established by UNMIK and therefore no need to muddy the waters by dragging out the process with personal interaction and discussion.

On the other hand, there may be a price to pay for the exclusion of concerned persons from the process. There are presently few situations in which members of the majority ethnic group (ethnic Albanians) and minority ethnic groups $^{85}$ (ethnic Serbs, Turks, Roma for example) are required to come face

83 E-mail communication with an HPD international staff member, 20 July 2003. This echoes comments by a former HPD international staff member: "What is there to negotiate? Either you own the property or you don't" (supra n 32).

84 E-mail communication with HPD international staff member, ibid.

85 Or "non-majority ethnic groups" as they are increasingly referred to amongst the international community in Kosovo. 
to face with each other. Providing a real opportunity for individuals to sit down together to reach an agreement on housing, even if it is simply to decide when the secondary occupier will leave, might have a positive effect on reconciliation. ${ }^{86}$

Further, the current approach seems to treat property rights as solely economic interests. While this is surely one part of the equation, the detached, mass claims rights-based approach ignores certain psychological realities surrounding human beings' relationships with their physical environments. Far from being solely economic, property rights, particularly in the structure that has served as a family's home for a few or many years, can play a key role in a person's sense of identity and indeed one's sense of security. Kearns et al hint at this dual relationship: ${ }^{87}$

"Housing is often considered as a consumption or asset good, meeting immediate needs such as for shelter, and in many cases also providing investment returns and access to other financial benefits via the ownership of equity. Less often do we consider the non-material, non-financial benefits of housing[.]",

Abramson and Theodossopoulos make similar observations. They identify two major types of relationships which people have with land, "the one finding strong moral and emotional identity with the estate, the other commercially objectifying it from a subjective distance". ${ }^{88}$ Exploring the emotional side of the equation, Saunders describes the home as a place " $[\mathrm{w}]$ here people feel in control of the environment, free from surveillance, free to be themselves and at ease, in the deepest psychological sense, in a world that might at times be experienced as threatening and uncontrollable." 89 While a streamlined, rights-based approach to property

86 I am not unmindful of criticisms made of mediation between individuals in other contexts, for example that there may be power imbalances between parties or (as has been the criticism in the present context) that a mediated settlement may be unsatisfactory for a party who feels s/he is completely in the right (see, for example: Grillo, "The Mediation Alternative: Process Dangers for Women" (1991) 100 Yale Law Journal 1545). However, others support mediation as a tool through which difficult relationships can be transformed and individuals empowered (see, for example: Bush and Folger, The Promise of Mediation [1994]; Rifkin, "Mediation from a Feminist Perspective: Promise and Problems" (1984) 2 Law and Inequality 21).

87 Kearn et al, "'Beyond Four Walls'. The Psycho-social Benefits of Home: Evidence from West Central Scotland" (2000), 15(3) Housing Studies 387 at 387.

88 Abramson and Theodossopoulos, Land, Law and Environment (2000), p 7.

89 Saunders, A Nation of Home Owners (1990), p 361. The term "home" is obviously rooted in the English language and as such one must be careful in the extent to which ideas surrounding it are applied in non-English cultural contexts. However enough work has been done into how the concept extends crossculturally that it seems justifiable to transfer the concept to other cultures, at least those which have a rather static (as opposed to nomadic) approach to housing and shelter [see, for example: Mandic and Clapham, "The Meaning of Home Ownership in the Transition from Socialism: The Example of Slovenia" (1996) 33 Urban Studies 83; Kent, "Ethnoarchaeology and the Concept of Home: A CrossCultural Analysis" in The Home: Words, Interpretations, Meanings, and Environments (1995) 163]. 
rights determinations may deal effectively with the economic side of property rights, it fails to recognise or address the emotional connection people form to their physical surroundings and the trauma they may experience upon losing their homes.

Such emotional connections may seem obvious with respect to the displaced persons who make HPD property claims (both from the perspective that they claim to be the legal owners or occupiers and in that in many cases they or their families will have resided in the dwelling in question for years, if not decades). But they equally be important to secondary occupiers, who have in many cases now lived in the contested dwellings for as many as five years. They, too, may feel a sense of loss in being forced to leave following an HPCC decision in favour of the claimant. Over the years that they have occupied the house, attachments will have formed to the physical spaces. Children have been born in these houses, weddings have taken place, family members have died, and physical changes or improvements have been made to accommodate the tastes and needs of those who have been living in the houses, all of which strengthens a family's connection to the place it occupies. ${ }^{90}$ Surely this has in some way become home to them.

One OSCE Human Rights Officer in Kosovo reported being present at an eviction in which the occupying family, having been given 14 days notice to leave the home they had occupied since the conflict, simply stood by on the expiry of the notice period and watched as HPD Evictions Officers emptied the house of their belongings. The Human Rights Officer wondered - was it simply disbelief on the part of the family that it would actually come to this (i.e. that HPD would actually get organized enough to perform an eviction)? Or a feeling that this had somehow become their home, regardless of what the property rights determination was, and they could/should not be forced to leave this way? ${ }^{91}$ The current approach ignores these factors in the hurry to protect the economic aspects of property rights.

90 Although most literature on displaced persons and "home" has tended to focus on home as the place from which people fled, a growing body of work is addressing the multiple ties a displaced person or family may feel, and indeed the numerous places which may serve as home, all in their own ways. See, for example: van Hear, "From durable solutions to transnational relations: Home and exile among refugee diasporas" (March 2003) UNHCR New Issues in Refugee Research Working Paper No. 83; Fog Olwig, "Epilogue: Contested Homes: Home-making and the Making of Anthropology" in Rapport and Dawson, eds., Migrants of Identity: Perceptions of Home in a World of Movement (1998) 225-236; Van Amersfoort, Transnationalisme, Moderne Diaspora's en Sociale Cohesie (2001); Holm Pederson, "Between homes: post-war return, emplacement, and the negotiation of belonging in Lebanon" (February 2003) UNHCR New Issues in Refugee Research Working Paper No. 79. Property law researchers are also increasingly challenging the widely-propogated notion that home ownership plays a significant role in the way a person connects to his/her physical environment, recognizing that significant connections may form even without a deed of ownership: see, for example, Mandic and Clapham, ibid. Granted, some adverse possessors/secondary occupiers are simply war profiteers who may by now have acquired several properties as a reward for their service during the conflict, but these are the minority of cases.

91 Interview with an OSCE Human Rights Officer, supra $\mathrm{n}$ 81. At the same time, the Human Rights Officer reported actively discouraging an OSCE colleague who 
Porteous and Smith write, "if home is the 'centre of the world', then losing home is "undoing the meaning of the world"..$^{92}$ Any mechanism designed to deal with housing and property restitution in a post-conflict context surely must take account of the impact that the loss of one's home has had or will have on a party to the claims procedure. The restitution process has the potential to bring individuals of differing ethnic groups face to face, and further to assist individuals in coming to terms with emotional losses sustained through the loss of "home". However, to do so, claimants would need a far greater level of involvement in process, either as active participants or at least involved observers, than is currently the case.

This is not to downplay the importance of housing and property restitution as a legal process, nor in any way to argue against the increasing momentum internationally towards the establishment of post-conflict restitution mechanisms. As Leckie writes, describing many situations worldwide, "Even when conditions may be secure and stable enough for return to occur, many millions of people continue to be prevented from returning to their homes of origin, recovering property or receiving compensation". ${ }^{93}$ Restitution mechanisms must therefore be encouraged.

However, unlike the situations which Leckie describes, in Kosovo conditions of security and stability do not yet exist for individuals who are ethnic minorities in the areas from which they originate. In a recent paper, the Deputy Special Representative of the United Nations Secretary General in Kosovo trumpeted the successes of the international community in ending ethnic conflict in Kosovo. One of the pitfalls, however, which he admitted the international community had not avoided was the failure to ensure the return of ethnic minority refugees. He stated: "Even though some [ethnic minorities] do return, many Serbs feel that the interethnic security situation is too fragile and the unemployment too high, to allow them to settle again in Kosovo." 94 Communities still show the scars of war, and while ethnic violence is much decreased since the official end of the conflict, horrendous acts are still occuring. ${ }^{55}$ Housing and property restitution is therefore not

proposed inviting the owners of a property to the eviction process of the occupying family - with the two parties having been excluded from the process up to that point, she felt having them meet face to face at the eviction would only invite trouble.

92 Porteous and Smith, Domicide: The Global Destruction of Home (2001), p 34.

93 Leckie, "Introduction - Going home: Land and property issues" (April 2000) 7 Forced Migration Review 4.

94 "Kosovo is good lesson in international action against ethnic conflict - UN official" (28 January 2004) UNMIK News Coverage, <www.unmikonline.org>.

95 The recent murder of an ethnic Serb family in Obiliq/Obilic, a village near Pristina/Prishtinë to which there had recently been some ethnic minority returns, is evidence of ongoing interethnic tension (see Breicevci, "Serb Family Murdered in Kosovo" (9 June 2003) Transitions On-line, <www.tol.cz> and "Press Statement on Kosovo by Security Council President", Press Release SC/7781, $<$ www.un.org $>$ ). See also Beardsley, "In Kosovo, former neighbours warily eye each other" (29 May 2002) Christian Science Monitor, <www.csmonitor.com>. While the depth of psychological wounds people carry from the war is still not fully understood, studies have concluded that a large portion of the local population is suffering from various psychological problems stemming from the conflict, with one study estimating that $67 \%$ of Kosovo Albanians are suffering 
simply a final step in the process in Kosovo but rather only one part of a challenge-filled movement to encourage returns.

Still, this is not necessarily to suggest that a rights-based approach to housing and property restitution in Kosovo is inappropriate: given the history of discrimination and the instrumental use of housing and property rights in the oppression of the ethnic Albanian community prior to the war, there are strong arguments in favour of using such an approach. ${ }^{96}$ However, a rightsbased process which allows parties some participation in - and therefore ownership over - decisions made, rather than pushing through in a hurried, mass-claims way, might prove to be much more successful in meeting the social goals of the housing and property restitution process in the long term. The slowing down of the process might be a small price to pay for a more effective outcome. International involvement in post-conflict areas is increasingly seen to be most successful when there is a long-term commitment to assist, rather than a short-sighted "do the job and leave" approach. ${ }^{97}$ After all, there is little use in finishing a task early at the expense of it having been of any use to the people it was meant to benefit. Greater involvement in the process and formalized opportunities for claimants to meet with members of other ethnic groups - including the person occupying their home - might allow some level of understanding to be reached which could help to lead to increased security and reconciliation in potential areas of return, and therefore more actual return.

from post-traumatic stress disorder (PTSD) [see Lama, "Kosovo: Psychological Wounds" (15 April 2003) Institute for War and Peace Reporting, <www.iwpr.net>].

96 However while generally beyond the scope of this article, it should briefly be asked here whether a different approach to finding solutions to housing and property issues of the displaced following situations of displacement - particularly where there is a protracted displacement and a lack of other conditions conducive to return - could be preferable to the approach currently finding favour in the international community. Could alternatives to a rights-based approach be tenable and justifiable at international law, while providing refugees and other displaced persons more "real" opportunities for return or other durable solutions to their displacement? For example, if conditions do not otherwise exist for the return of refugees and IDPs, could a workable system of compensation or other assistance be implemented for displaced persons in place of the restitution of their property (which they would only sell anyways) to help them integrate locally into the area where they have taken refuge? Could housing be provided in parts of the area/country of return other than the village from which the displaced person came? These options raise important concerns of international law and human rights and do not provide the satisfying solution of having reversed the "ethnic cleansing" which has taken place during the conflict. As such they are often rejected out of hand by international organizations. Yet it is worth asking whether in some cases, particularly in protracted refugee/IDP situations, such approaches might have the impact of ensuring a right to housing which can actually be enjoyed.

97 See, for example: Weiss Fagen, "Post-Conflict Reintegration and Reconstruction: Doing It Right Takes a While" in Steiner et al, eds, Problems of Protection: The UNHCR, Refugees, and Human Rights (2003) 197. 


\section{CONCLUSION}

To date the international community has taken an approach to housing and property restitution in Kosovo which is almost entirely based on determining rights on paper. This approach offers simplicity of mandate and implementation, thereby allowing a "quick" completion of the task. However, it also ignores a key original goal of the process - providing conditions for successful and widespread return of displaced populations. To accomplish this larger goal what is necessary is not only a right in principle to property but a real possibility to return to one's home in conditions of economic stability and security.

The formal protection of property rights is important. But the protection of a property right which cannot be exercised except by alienation of the right may arguably not be worth the trouble. In a world of limited budgets and human resources the international community needs to reconsider what is being done to encourage returns, and come to terms with the fact that its current HPD approach in Kosovo may actually be negating positive steps towards return taken by other organisations. A more coordinated approach, even if it takes a little longer, may prove far preferable. 